\title{
Aleksandra Skrzypietz
}

\section{Teatr domowy królowej Marii} Kazimiery w świetle jej korespondencji z najstarszym synem

\author{
Marie Casimire d'Arquien's Home Theatre \\ in Her Correspondence with Her Eldest Son
}

\section{Abstrakt}

Celem artykułu jest pokazanie rzymskiego teatru domowego królowej Marii Kazimiery Sobieskiej jako tematu, który poruszała w listach. Podstawę źródłową stanowi korespondencja monarchini z najstarszym synem; są to źródła jednostronne, gdyż znane są jedynie listy królowej, a nie zachowały się lub nie zostały odnalezione listy królewicza Jakuba. W 1698 r. owdowiała Maria Kazimiera opuściła Polskę i przeniosła się do Rzymu, by spędzić tam rok jubileuszowy. Okazało się, że pozostała nad Tybrem prawie piętnaście lat. Idąc w ślady królowej Krystyny, zapragnęła opiekować się artystami, a ponieważ już w Rzeczypospolitej organizowała przedstawienia teatralne na swym dworze, zatem i w Rzymie postanowiła patronować występom muzycznym, teatralnym i operowym. W tym przedsięwzięciu pomagał jej królewicz Aleksander, który także zamieszkał w Rzymie. Szybko okazało się, że syn jest nie tylko aktywnym mecenasem, ale ma także uzdolnienia artystyczne i zmysł pozwalający mu wcielić się w rolę reżysera, scenarzysty, a nawet tancerza w scenach baletowych. W przygotowanie przedstawień zaangażowała się także wnuczka i imienniczka królowej, Maria Kazimiera. U boku stryja uczyła się sztuki przygotowywania przedstawień, ale brała również udział w scenach baletowych. W swoich listach 
do najstarszego syna, Jakuba, królowa zachwycała się wszechstronnymi talentami obojga i zapewniała, że nie szczędzi pieniędzy i wysiłków, by dostarczyć im okazji do zabawy, a sobie i swojemu teatrowi przysporzyć splendoru i szerokiego odbioru. W korespondencji królowa nigdy nie poruszała kwestii związanych z samymi przedstawieniami, nie podawała ich tytułów, nie pisała nic o tematach, których dotyczyły. Z korespondencji królowej nie można dowiedzieć się zbyt wiele o jej teatrze domowym, ale napisane jest dużo na temat dumy, jak ją przenikała na myśl o osiągnięciach artystycznych syna i wnuczki. Listy są bowiem świadectwem uczuć królowej, a nie sprawozdaniem z życia jej rzymskiego dworu.

Słowa klucze: Sobiescy, korespondencja, mecenat, propaganda, teatr

\section{Abstract}

The purpose of this article is to show the Roman home theatre of Queen Marie Casimire de La Grange d'Arquien as a topic she addressed in her letters. The sources are based on her correspondence with her eldest son; these sources are one-sided, as only the queen's letters are known, while the letters of Prince James have not survived or have not been found. In 1698, the widowed Marie Casimire left Poland and moved to Rome to spend the Jubilee year there. Eventually, she remained on the Tiber for almost fifteen years. Following in the footsteps of Queen Christina, she wished to be a patron of artists, and since she had already organized theatrical performances at her court in Poland, she decided to patronize musical, theatrical and operatic performances in Rome as well. She was assisted in this endeavor by Prince Alexander, who also resided in Rome. It soon became apparent that her son was not only an active patron, but also had artistic talents and an aptitude to take on the role of director, writer, and even a dancer in ballet scenes. The queen's granddaughter and namesake, Marie Casimire, was also involved in preparing the performances. At her uncle's side, she learned the art of preparing performances, but she also took part in ballet scenes. In her letters to her eldest son, James, the Queen marveled at the versatile talents of both and assured him that she would spare no expense or effort to provide them with opportunities to entertain, and to bring splendor and widespread acceptance to herself and her theatre. In her correspondence, the Queen never touched on the topic of the plays themselves, gave their titles, or wrote anything about the subjects they addressed. From the Queen's correspondence, one cannot learn much about her home theatre, but much about the pride that filled her at the thought of her son's and granddaughter's artistic achievements. The letters are a testimony to the queen's feelings, not a report of the life of her Roman court.

Keywords: Sobieski family, correspondence, patronage, propaganda, theatre 
W 1698 r., wobec porażki elekcyjnej królewicza Jakuba Sobieskiego, owdowiała królowa Maria Kazimiera postanowiła opuścić Rzeczpospolitą. Uznała, że nie ma dla niej nad Wisłą miejsca, gdyż nie będzie tu traktowana z należytą atencją. Zwróciła się zatem do króla Augusta II i sejmu z prośbą o pozwolenie na wyjazd do Rzymu w związku z nadchodzącym rokiem jubileuszowym ${ }^{1}$. Ostatecznie jej pobyt nad Tybrem wydłużył się i do Polski już nigdy nie powróciła. W 1714 r. w poszukiwaniu, spokoju, oszczędności finansowych i zdrowia przeniosła się do Francji i tam w królewskim zamku w Blois zmarła u progu 1716 r. $^{2}$

Wyjeżdżając z Polski, królowa zabrała ze sobą swą najstarszą wnuczkę i imienniczkę „królewnisię” - jak nazywano wnuczki królewskie - Marię Kazimierę, która do końca życia monarchini pozostała u jej boku i pod jej opieką. Do Italii pojechał także ojciec królowej, Henryk de la Grange d’Arquien, od 1696 r. kardynał, który pozostał na rzymskim dworze córki do swej śmierci w 1707 r. Po kilku latach dołączył do nich także królewicz Aleksander, który zobowiązał się, że opuści Rzeczpospolitą po uwolnieniu swoich braci, Jakuba i Konstantego, którzy w latach 1704-1706 byli więzieni w Saksonii, gdy August II postanowił pozbyć się Jakuba Sobieskiego jako rywala do korony, wspieranego przez Karola XII ${ }^{3}$.

Pobyt nad Tybrem przyniósł zaskakujący i bezcenny owoc $\mathrm{w}$ postaci korespondencji królowej z najstarszym synem. Jest ona nieocenionym źródłem wiedzy na temat sytuacji rodziny i wielu aspektów życia jej członków. Wiąże się z nią jednak kilka poważnych problemów, na które trzeba koniecznie zwrócić uwagę. Przede wszystkim jest to źródło jednostronne, gdyż królowa pisywała do Jakuba regularnie, a odpowiedzi otrzymywała raczej rzadko, na co często skarżyła się w swoich listach. Wydaje się, że do młodszych synów pisywała rzadziej, a i oni nie byli obowiązkowi w wysyłaniu odpowiedzi. Co ważniejsze - choć nie wiadomo, jak często do królowej docierały listy synów - dotychczas nie udało się ich odszukać. Być może zostały zniszczone już w Blois, gdy likwidowano dwór królowej i przygotowywano się do wywiezienia pozostałych po niej rzeczy. Wówczas kwestią najważniejszą było przemycenie do Polski jej trumny, jako że słudzy Sobieskich nie otrzymali zezwolenia na zabranie

1 Michał Komaszyński, Maria Kazimiera d Arquien Sobieska królowa Polski (1641-1716) (Kraków: Wydawnictwo Literackie, 1983), 212.

2 Ibidem, passim.

3 Kazimierz Jarochowski, Dzieje panowania Augusta II od wstapienia Karola XII na ziemię polską aż do elekcji Stanisława Leszczyńskiego (1702-1704) (Poznań: nakładem i czcionkami Ludwika Merzbacha, 1874), 502-517; Komaszyński, Maria Kazimiera, 214-262; Aleksandra Skrzypietz, Królewscy synowie - Jakub, Aleksander i Konstanty Sobiescy (Katowice: Wydawnictwo Uniwersytetu Śląskiego, 2011), 359-512. 
zwłok królowej, póki nie zostaną uregulowane jej długi ${ }^{4}$. Wbrew temu zakazowi, ciało Marii Kazimiery znalazło się w Warszawie w klasztorze kapucynów, gdzie od 1696 r. spoczywały zwłoki jej królewskiego małżonka, oczekujące na uroczysty pogrzeb na Wawelu․ W tej sytuacji, wobec zamieszania, które musiało panować na osieroconym dworze, nietrudno wyobrazić sobie, że papiery pozostałe po królowej uznano za najmniej ważne i pozostawiono je w Blois. Być może zresztą korespondencja ta czeka jeszcze na ujawnienie, skoro bowiem odnalazło się archiwum Sobieskich z Oławy, które uważano za zaginione po II wojnie światowej, to i inne materiały mogą zostać odkryte.

Korzystanie z korespondencji królowej utrudnia nie tylko jednostronność przekazu, ale i fakt, że Maria Kazimiera zazwyczaj nie wpisywała w listach daty rocznej. Co oczywiste, zarówno ona, jak i odbiorca wiedzieli, w którym roku list powstawał, zatem królowa zapisywała jedynie datę dzienną, często pomijając także miejsce pisania listów. Być może wychodziła z założenia, że skoro nie zaznaczyła inaczej, list powstał w Wiecznym Mieście. Nie można jednak mieć całkowitej pewności, że listy bez oznaczonego miejsca pisane były właśnie tam. Natomiast brak daty rocznej zwykle uniemożliwia ustalenie, kiedy dany list powstał. Jeszcze w Berlinie, gdzie trafily z Oławy, listy te zostały zebrane w poszyty i znajdują się w nich nadal, jednak datom rocznym, przypisanym tym wyodrębnionym grupom listów, nie wolno ufać6. Dokumenty w nich umieszczone noszą kolejne daty dzienne, co czyni wrażenie, że są uszeregowane chronologicznie, a tymczasem z pewnością tak nie jest. Najbardziej oczywisty przykład, potwierdzający, że nie wolno zawierzać temu podziałowi, odnosi się do dwóch listów o sygnaturze 174. 25 kwietnia Maria Kazimiera pisała o swej radości, iż Jadwiga Elżbieta wstała z połogu, a jest to tym lepsza nowina, że poród był bardzo ciężki. Dziecko urodziło się martwe lub zmarło - bo nie ma o nim wzmianki - i najpewniej do tego odnosi się uwaga królowej, że nie przekazała tej smutnej

4 Michał Komaszyński, „Filip Dupont - dworzanin doskonały”, w Studia z dziejów epoki Jana III Sobieskiego, red. Krystyn Matwijowski, Acta Universitatis Wratislaviensis, Historia, t. 37 (Wrocław: Wydawnictwo Uniwersytetu Wrocławskiego, 1984), 208; Michał Komaszyński, „Tajemnicza podróż trumny z prochami „Marysieńki” Sobieskiej do Polski”, Acta Universitatis Wratislaviensis, Historia 66 (1988): 237.

5 Aleksandra Skrzypietz, „Infant Jan, czyli ostatni królewski pogrzeb na Wawelu”, $\mathrm{w} W$ podróży przez wiek osiemnasty. Studia i szkice z epoki nowożytnej, red. Adam Perłakowski, Michał Zwierzykowski, Monika Wyszomirska (Kraków: Księgarnia Akademicka, 2015), 71-91.

6 Jakiś czas temu listy zostały wyodrębnione z fondu 694 (Radziwiłłów) w fond 695 (Sobieskich), ale materiały w mińskim archiwum zbierałam wówczas, gdy fondy nie były jeszcze rozdzielone. 
wiadomości swej wnuczce ${ }^{7}$ W jednym z kolejnych - jak mogłoby się wydawać - listów, królowa wyraziła nadzieję, że Jadwiga Elżbieta urodzi szczęśliwie ${ }^{8}$. Rzecz oczywista, królewiczowa nie mogła w tym krótkim czasie zajść w ciążę, wiedzieć, że jest brzemienna i poinformować o tym teściową. Zatem widać wyraźnie, że choć pozornie listy ułożone zostały chronologicznie - jeden powstał w końcu kwietnia, a drugi na początku maja - to z pewnością nie pochodzą z tego samego roku. Takich niespodzianek jest w omawianym zbiorze znacznie więcej, toteż najbezpieczniej jest odwoływać się do listów bez podawania ich kolejności i bez próby datowania rocznego, chyba że - co się czasem zdarza - w liście podane są wydarzenia, które datować można bez najmniejszych wątpliwości.

$\mathrm{Z}$ powyższego względu narracja w niniejszym artykule została skonstruowana tak, by tworzyć w miarę zwartą całość, ale nie sposób ustalić, czy listy omawiające pewne zbliżone kwestie powstawały w jednym okresie, czy też dzielił je długi czas. Nie wiadomo nawet, czy uwagi w nich zawarte odnoszą się do wydarzeń z jednego, czy z kilku różnych sezonów, gdy działał teatr Marii Kazimiery. Ustalenie daty rocznej lub nawet kolejności powstania większości wykorzystanych tu listów jest niemożliwe tym bardziej, że królowa w tym samym piśmie potrafiła poruszać zupełnie różne, a nawet nieprzystające do siebie kwestie. Radość mieszała się nich ze smutkiem, ważne problemy sąsiadowały z drobiazgami, a myśl autorki płynęła czasem niepowstrzymanym nurtem, z łatwością i dosłownie, bez przerwy - również graficznej - przechodząc z jednego tematu w drugi.

W drodze do Italii Maria Kazimiera została wspaniale przyjęta. Najpierw ją i jej synów oraz wnuczkę powitała w Wiedniu rodzina cesarska. Potem kolejne państwa włoskie prześcigały się w radosnych ceremoniach, którymi uczcić chciały wdowę po zwycięzcy Turków. Uznawano bowiem, że w 1683 r. Jan III uratował ich przed bezpośrednim zagrożeniem, jakie grozić im miało, gdyby Kara Mustafa zwyciężył. Był to zatem tryumf polskiej królowej, który odbierała przez wzgląd na dokonania swego zmarłego małżonka'.

7 Maria Kazimiera do Jakuba Sobieskiego, Rzym, 25 IV [?], Nacyjanalnyj Gistarycznyj Archiu Biełarusi w Mińsku [dalej cyt.: NGAB] fond 694, opis 12, rkps 174, k. 32r-34r.

8 Maria Kazimiera do Jakuba Sobieskiego, Rzym, 9 V [?], NGAB f. 694, o. 12, rkps 174, k. 48r-50r.

9 Komaszyński, Maria Kazimiera d Arquien, 214-223. 
Maria Kazimiera nie zamierzała pozostać w Wiecznym Mieście mało znaczącym gościem, a wydaje się, że w miarę upływu czasu - z pewnością uradowana uroczystym powitaniem - nabierała przekonania, że należy jej się najwyższa, po papieżu, pozycja. W Rzymie nie było kobiety, która „z urzędu” zajmowałaby wysokie miejsce, zatem to, co straciła, opuszczając Polskę, Sobieska mogła odzyskać podczas udziału w ceremoniach papieskich. Nie ulega wątpliwości, że wzorowała się w tej kwestii na królowej Krystynie, która z górą trzydzieści lat spędziła w Rzymie i tam - całkiem niedawno, bo w 1689 r. - zmarła. Do pozycji szwedzkiej królowej i swoich ambicji w tej mierze Sobieska nawiązywała $\mathrm{w}$ korespondencji z synem ${ }^{10}$. Nie chodziło zresztą jedynie o ceremonie i pozycję, którą powinna zajmować. W jednym ze swoich listów królowa wyznała, że podobnie jak przedtem Krystyna, tak i ona chciałaby patronować akademii i artystom ${ }^{11}$. Królowa szwedzka gorliwie zajmowała się mecenatem, opiekując się m.in. teatrem ${ }^{12}$. Toteż idąc w jej ślady, polska królowa również stała się patronką twórców i organizatorką wydarzeń artystycznych. Służyć to miało upamiętnieniu dokonań Jana III i utrwaleniu jego pamięci, ale powinno także podnieść jej własną pozycję jako jego małżonki i mecenasa. Warto dodać, że królowa miała spore doświadczenie w organizacji przedstawień, gdyż na jej dworze w Polsce spektakle teatralne były częstym elementem uroczystości dworskich ${ }^{13}$.

$\mathrm{Z}$ czasem okazało się, że znaczącą rolę w spełnieniu marzeń Marii Kazimiery odegrał królewicz Aleksander, który od 1709 r. był członkiem rzymskiej Akademii Arkadii. Pragnąc wejść w ten krąg, Sobieski sfinansował tom pism sekretarza akademii Giovanniego Marii Crescimbeniego, a ostatecznie został nie tylko mecenasem, ale i poetą o pseudonimie Armonte Calidio. Również królowa dołączyła do tego świetnego grona i została honorowym członkiem akademii jako Amirisca Telea ${ }^{14}$.

10 Maria Kazimiera do Jakuba Sobieskiego, Rzym, 10 VIII [?]. NGAB f. 694, o. 12, rkps 159, k. 15r-20v; Maria Kazimiera do Jakuba Sobieskiego, Rzym, 23 I [?]. NGAB f. 694, o. 12 , rkps 165 , k. 1r-15r.

11 Maria Kazimiera do Jakuba Sobieskiego, Rzym, 10 VIII [?], NGAB f. 694, o. 12, rkps 159, k. 15r-20v.

12 Alfred Neumann, Krystyna królowa szwedzka, przekł. Marceli Tarnowski (Warszawa: Powszechna Spółka Wydawnicza „Płomień, 1987), 281-286; Marie-Louise Rodén, Queen Christina (Lund: Svenska Institutet, 1998), 27; Sven Stolpe, Królowa Krystyna, przekł. Maria Olszańska (Warszawa: Państwowy Instytut Wydawniczy, 1988), 418-420.

13 Karolina Targosz, Francuski teatr królowej Marysieńki (Warszawa: Muzeum Pałacu Króla Jana III w Wilanowie, 2012), passim.

14 Wanda Roszkowska, „Polacy w rzymskiej «Arkadii» (1699-1766)”, Przeglad Literacki 56 (1965): 46; Wanda Roszkowska, „Mecenat królewicza Aleksandra - teatr Armonte Calidio (1709-1714)", Śląski Kwartalnik Historyczny Sobótka 35 (1980): 313-314; 
Nie jest zupełnie jasne, kiedy w Palazzo Zuccari - rzymskiej siedzibie Marii Kazimiery - zaczęto organizować przedstawienia. Wydaje się, że od początku jej pobytu w Rzymie wystawiano sztuki przygotowane przez trupy włoskie, a odbywały się także koncerty. Moda zakładała, że mimo niechęci papieża balety mogą otwierać bale organizowane w arystokratycznych rezydencjach. Wanda Roszkowska twierdzi, że już od sezonu 1706/1707 istniał w rezydencji Sobieskiej Palazzo Zuccari na Trinità de'Monte „piccolo teatro”, a opiekował się nim Carlo Sigismondo Capece, od 1704 r. sekretarz królowej ${ }^{15}$. Na przełomie lat 1709 i 1710 teatr królowej nabrał rozmachu dzięki zainteresowaniu królewicza Aleksandra ${ }^{16}$, a pomagała mu „królewnisia” Maria Kazimiera, angażując się - podobnie jak wuj - w przygotowanie sztuk i biorąc w nich udział. Niewątpliwie stało się to pasją królewicza, który - jak już wspomniano - najdalej w $1711 \mathrm{r}$. osiadł u boku matki w Rzymie na stałe, ale z pewnością regularnie bywał tam wcześniej ${ }^{17}$. Według Wandy Roszkowskiej, królewicz odznaczał się „inteligencją i wyrafinowanym gustem”, ${ }^{18}$ a w Arkadii dyskutowano nad wynaturzeniem ówczesnego dramatu przeładowanego oderwanymi od narracji scenami służącymi popisom artystów. „Spoistość struktury domagała się kompozycji logicznej, oczyszczenia z nie związanych z wątkiem głównym epizodów, honorowania zasady prawdopodobieństwa"19 opartych na tematach historycznych i mitologicznych, zaś fabuła miała służyć pożytkowi moralnemu. Przedstawiano więc szlachetne uczucia: miłość, przyjaźń, wierność, rodzinne ciepło i lojalność, a wszystko to powinno wiązać się z wizją sceniczną i harmonijnie układać się w całość. Królewicz Aleksander opowiadał się za takim właśnie powiązaniem treści z muzyką i wszystkimi pozostałymi walorami przedstawienia. W teatrze Marii Kazimiery to on decydował o doborze tematów, muzyki, kostiumów i wykonawców. Postrzegać go więc należy "jako rasowego człowieka teatru, reżysera obdarzonego konkretną, przemyślaną wizją spektaklu"20. Współpracowali z nim twórca librett Carlo Sigismundo Capece i muzyki Domenico Scarlatti, również sekretarz królowej, oraz

Karolina Targosz, Sawantki w Polsce XVII wieku. Aspiracje intelektualne kobiet ze środowisk dworskich (Warszawa: Wydawnictwo Retro-Art, 1993), 475.

15 Aneta Markuszewska, Festa i muzyka na dworze Marii Kazimiery Sobieskiej w Rzymie (1699-1714) (Wilanów: Muzeum Pałac w Wilanowie, 2012), 123-125; Roszkowska, „Mecenat królewicza Aleksandra”, 312.

16 AE Rome 497, k. 281.

17 Skrzypietz, Królewscy synowie, 499.

18 Roszkowska, „Mecenat królewicza Aleksandra”, 313.

19 Ibidem, 314.

20 Ibidem, 315. 
scenograf Filippo Juvarra, działający także w teatrze kardynała Pietro Ottoboni ${ }^{21}$. Aleksander zatrudnił też sprowadzonego ze Śląska muzyka Sylwiusza Leopolda Weissa.

Temat teatru pojawiał się w listach królowej nieodmiennie w kilku aspektach. Pisała o udziale królewicza Aleksandra w powstaniu przedstawień, ale także o jego chorobie, która w tym przeszkadzała. Ważną częścią opowieści, czy raczej uwag królowej, była również aktywność „królewnisi” Marii Kazimiery oraz kwestie rywalizacji z innymi scenami rzymskimi, a wreszcie pieniędzy, których to wymagało.

W początkach $1707 \mathrm{r}$. królowa zapraszała właśnie uwolnionych z saskiego więzienia synów do siebie. Chciała ich zobaczyć i przytulić po latach pełnych strachu i bólu, ale wabiła Jakuba obietnicą, że zobaczy swą najstarszą córkę „w małym balecie”22, w teatrze domowym. Przedstawienie - według przekazu królowej - przygotowywano na cześć Karola XII i w związku z odzyskaniem przez Jakuba i Konstantego wolności. Królowa dokładnie przedstawiła okoliczności przygotowań do występu - to cesarzowa Eleonora, ciotka „królewnisi”, napisała do niej o szczęśliwym uwolnieniu jej ojca i stryja. Poinformowane o tym babka i wnuczka czekały stęsknione na królewiczów ${ }^{23}$. Zapewne sztuka, którą przygotowywano, miała rozpropagować radosną wieść o ich uwolnieniu, a przy okazji przypomnieć o zasługach Sobieskich oraz okrucieństwie i niemoralnym postępowaniu Augusta II. Nie należy bowiem wątpić, że treść przedstawienia zgrabnie łączyła się z tym najważniejszym dla rodziny wydarzeniem. Jednakże ani Jakub, ani Konstanty nie pojawili się wówczas nad Tybrem.

Nie wiadomo, czy w związku z udziałem swej wnuczki w balecie, czy jedynie $w$ balach, królowa $z$ dumą i zachwytem donosiła najstarszemu synowi, że jego córka tańczy menueta $\mathrm{z}$ wielką gracją, a zdaniem zachwyconej babki jest najładniejsza na świecie ${ }^{24}$. Nie można ustalić, kiedy się to wydarzyło, ale z pewnością „królewnisia” od najmłodszych lat uczyła się tańca, zarówno po to, by poznać figury związane z nim, ale także - co

21 Markuszewska, Festa i muzyka, 141; Roszkowska, „Mecenat królewicza Aleksandra”, 311-321; Wanda Roszkowska, „Prace Filipa Juvarry dla teatru i rzymskiej rezydencji Sobieskich", Biuletyn Historii Sztuki 46 (1984): 257-269.

22 Maria Kazimiera do Jakuba Sobieskiego, Rzym, 26 II [?], NGAB f. 694, o. 12, rkps 170, k. $41 \mathrm{r}-62 \mathrm{v}$.

23 Ibidem.

24 Maria Kazimiera do Jakuba Sobieskiego, Rzym, 6 XII [?], NGAB f. 694, o. 12, rkps 165, k. $160 \mathrm{r}-161 \mathrm{v}$ 
było zgodne z ówczesną modą - by prosto trzymać ciało, poruszać się lekko i z wdziękiem ${ }^{25}$.

Temat teatru i udziału w nim młodziutkiej Marii Kazimiery często pojawiał się korespondencji królowej. Nie trzeba dodawać, że wieści o tym związane były z nadchodzącym lub trwającym sezonem, czyli zawsze zimą. Królowa donosiła Jakubowi, że w jednym z przedstawień „królewnisia” była Dianą ${ }^{26}$. Maria Kazimiera odgrywała także rolę królowej i Aurory, a przy tym według babki pięknie tańczyła ${ }^{27}$. W innym liście królowa podkreślała, że cały świat jest oczarowany tańcem „królewnisi”28. Kiedy indziej znów cieszyła się, ponieważ wszyscy chwalili wnuczkę ${ }^{29}$, ale też - jak donosiła synowi - nie oszczędzała na edukacji jego córki ${ }^{30}$, co przynosiło efekty i pozwalało Marii Kazimierze odnosić sukcesy nie tyle artystyczne, ile towarzyskie. Młodziutka „królewnisia” była bardzo aktywna, chciała uczestniczyć w przyjemnościach karnawału i prosiła babkę o ładny strój maskaradowy, co królowa uznała za zupełnie oczywiste. Zamierzała spełnić to życzenie wnuczki, skoro miało sprawić jej przyjemnośćcis.

To właśnie zabawa i sukces towarzyski stawały się w opowieści królowej celem, który starała się zapewnić swoim pupilom - Marii Kazimierze i Aleksandrowi. Pisała więc do Jakuba, że jego brat świetnie się bawił podczas ostatnich dni karnawału ${ }^{32}$. Młodzi powinni się bawić, więc królowa nie zamierzała im niczego odmawiać. Karnawał był czasem, gdy „królewnisia” miała prawo - zdaniem babki - zaistnieć na rzymskich salonach ${ }^{33}$, nawet jeżeli wiązało się to $\mathrm{z}$ dużymi wydatkami.

25 Wojciech Klimczyk, Wirus mobilizacji. Taniec a kształtowanie się nowoczesności (14551795), t. 1: Dworskie kroki (Kraków: Universitas, 2015), 257-308.

26 Maria Kazimiera do Jakuba Sobieskiego, [b. m.] 8 XII [?], NGAB f. 694, o. 12, rkps 172, k. $89 \mathrm{r}-90 \mathrm{v}$

27 Maria Kazimiera do Jakuba Sobieskiego, Rzym, 26.01.[?], NGAB f.694, o.12, rkps 174, k. $10 \mathrm{r}-12 \mathrm{v}$.

28 Maria Kazimiera do Jakuba Sobieskiego, Rzym, 12 III [?], NGAB f. 694, o. 12, rkps 170, k. $46 \mathrm{r}-47 \mathrm{r}$

29 Maria Kazimiera do Jakuba Sobieskiego, Rzym, 29 XI [?], NGAB f. 694, o. 12, rkps 172, k. $95 \mathrm{r}-97 \mathrm{v}$.

30 Maria Kazimiera do Jakuba Sobieskiego, [b. m.] 27 VI [?], NGAB f. 694, o. 12, rkps 173, k. $1 \mathrm{r}-2 \mathrm{v}$

31 Maria Kazimiera do Jakuba Sobieskiego, [b. m.] 6 II [?], NGAB f. 694, o. 12, rkps 175, k. $9 \mathrm{r}-10 \mathrm{v}$.

32 Maria Kazimiera do Jakuba Sobieskiego, Rzym, 5 II [?], NGAB f. 694, o. 12, rkps 166, k. $125 \mathrm{r}-128 \mathrm{r}$.

33 Maria Kazimiera do Jakuba Sobieskiego, [b. m.] 22 II [?], NGAB f. 694, o. 12, rkps 173, k. $44 \mathrm{r}-\mathrm{v}$. 
Takie podejście do zabaw karnawałowych potwierdzał list, w którym królowa podsumowywała, że tego roku - znów nie wiadomo, którego Maria Kazimiera doskonale się bawiła przez cały karnawał i poznała wielu odpowiednich ludzi ${ }^{34}$. Czasem królewicz Aleksander uczestniczył w maskaradach razem z bratanicą $a^{35}$. Zdaniem królowej - matki i babki zarazem - „przyjemnie [było] popatrzeć”36, jak tańczyli razem. Więcej szczegółów zawarła w liście z 1713 r., gdy „królewnisia” dostała nową suknię, by doskonale się prezentować, gdy przyjmować będzie kardynałów, którzy licznie pojawiali się w Palazzo Zuccari, żegnając się z obydwiema Sobieskimi, które przygotowywały się do wyjazdu do Francji. Szata była "pąsowa welurowa ze srebrnymi i złotymi kwiatami” ${ }^{37} \mathrm{z}$ bardzo bogatego materiału. Po raz kolejny podziwiając wnuczkę, królowa zauważyła, że panna wyrosła i z żalem dodawała "dla mnie za szybko" 38 .

Królowa chwaliła syna i wnuczkę, twierdząc, że oboje ładnie tańczą, a „królewnisia” bardzo lubi teatr domowy ${ }^{39}$. Jej zdaniem oboje - Aleksander i Maria Kazimiera - bawili się przy tym świetnie, a było to tym bardziej naturalne, że przecież oboje - jak podkreślała królowa - byli młodzi ${ }^{40}$. W innym liście zaznaczyła, że Maria Kazimiera kocha i szanuje Aleksandra ${ }^{41}$. Królowa tak bardzo doceniała pracę, którą syn wkładał w funkcjonowanie jej teatru domowego, że usprawiedliwiała przed królewiczem Jakubem milczenie Aleksandra, który był zbyt zajęty, by pisać do brata ${ }^{42}$.

Warto dodać, że prócz przytoczonej już wzmianki o sztuce wystawionej w początkach 1707 r., w związku z uwolnieniem królewiczów z niewoli saskiej, teatr nie pojawia się w listach królowej aż do chwili, gdy to

34 Maria Kazimiera do Jakuba Sobieskiego, Rzym 13 II [?], k. 12r-18v NGAB f. 694, o. 12, rkps 175, k. 12r-18v.

35 Maria Kazimiera do Jakuba Sobieskiego, Rzym, 16 II [?], NGAB f. 694, o. 12, rkps 177, k. 28r-31v.

36 Maria Kazimiera do Jakuba Sobieskiego, Rzym, 26 I [?], NGAB f. 694, o. 12, rkps 172, k. $15 \mathrm{r}-17 \mathrm{v}$.

37 Maria Kazimiera do Jakuba Sobieskiego, [b. m.] 27 XII [?], NGAB f. 694, o. 12, rkps 174, k. 199-200r.

38 Ibidem.

39 Maria Kazimiera do Jakuba Sobieskiego, [b. m.] 10 XI [?], NGAB f. 694, o. 12, rkps 172, k. 78r-79v.

40 Maria Kazimiera do Jakuba Sobieskiego, [b. m., b. d.] NGAB f. 694, o. 12, rkps 173, k. 26r-27r.

41 Maria Kazimiera do Jakuba Sobieskiego, [b. m.] 3 X [?], NGAB f. 694, o. 12, rkps 172, k. $61-63 \mathrm{v}$.

42 Maria Kazimiera do Jakuba Sobieskiego, [b. m.] 9 XI [?], NGAB f. 694, o. 12, rkps 173, k. 16r-v. 
królewicz Aleksander zaczął ogrywać w nim znaczącą rolę. Wówczas to matka wychwalała go, pisząc, jak dobrze królewicz bawi się, organizując przedstawienia. Jej zdaniem ma dobry gust i „koryguje nawet mojego mistrza, który jest wielce uzdolniony"43, choć nie do końca wiadomo, o którego mistrza chodziło - Capecego czy Scarlattiego. Według matki królewicz był jednocześnie organizatorem - $\mathrm{w}$ najszerszym tego słowa znaczeniu - przedstawień, ale także aktorem. Zapewne i on - podobnie jak bratanica - brał udział w balecie. Nie tylko zdaniem królowej, ale - według niej - także wszystkich cudzoziemców, karnawał, który opisywała, był najcudowniejszy ze wszystkich.

Maria Kazimiera cieszyła się sukcesami swego syna i teatru pod jego kierownictwem, ale zarazem martwiła pogarszającym się zdrowiem Aleksandra. Królewicz chorował niemal od początku swego pobytu w Rzymie i królowa wspominała o pigułkach, które przyjmował ${ }^{44}$. Ponoć kuracja miała trwać jeszcze jakiś czas. Jeżeli były to pigułki, o których wspominano w źródłach francuskich, to trzeba dodać, że uważano, iż to właśnie one bardzo poważnie mu zaszkodziły i ostatecznie wyniszczyły jego organizm ${ }^{45}$. W jakiś czas po przybyciu nad Tyber Aleksander poważnie zaniemógł i wiele lat walczył z nieuleczalną - jak się okazało - chorobą ${ }^{46}$.

Tymczasem zamiłowanie Marii Kazimiery do teatru było tak wielkie, że choć wiele słów poświęciła chorobie Aleksandra, to w jednym z listów martwiła się co prawda, że syn jest chory, ale równocześnie żaliła się na tę słabość, która może przeszkodzić mu w pracy nad ukończeniem nowego spektaklu. Aleksander był chory na tyle poważnie, że nie mógł opuścić łóżka, a czekało go jeszcze mnóstwo pracy ${ }^{47}$. Innym razem w podobnym duchu królowa martwiła się chorobą syna, ale - jakby na

43 Maria Kazimiera do Jakuba Sobieskiego, [b. m.] 18 II [?], NGAB f. 694, o. 12, rkps 178, k. 114r-118r.

44 Ibidem.

45 Notatka o śmierci Aleksandra Sobieskiego, HHSTA, Polen rkps I/88, nie pag; Correspondance des directeurs de l'Académie de France à Rome avec Surintendants des Batiments publiée d'après les manuscripts des Archives nationals par M. A. de Montaiglon sous le patronage de la direction des Beaux-Arts, t. 3: 1699-1711 (Paris: Charavay Frères, Libraies de la Sociéte de l'histoire de l'art. Français 1889), 343-344; Aleksandra Skrzypietz, „Choroby królewicza Aleksandra Sobieskiego i porady lekarskie z nimi związane”, Kronika Zamkowa. Roczniki. Seria Nowa 71 (2018): 107-121.

46 Aleksandra Skrzypietz, „Uświęcenie grzesznika - burzliwy żywot królewicza Aleksandra Sobieskiego. w Staropolski ogląd świata. Kultura staropolska - poszukiwanie sacrum odnajdywanie profanum, red. Bogdan Rok, Filip Wolański (Toruń: Wydawnictwo Adam Marszałek, 2013), 297-324.

47 Maria Kazimiera do Jakuba Sobieskiego, Rzym, 20 XII [?], NGAB f. 694, o. 12, rkps 173, k. 130r-131v. 
pocieszenie - dodawała, że wnuczka czuje się dobrze. Oboje bardzo się natrudzili, przez trzy tygodnie przygotowując przedstawienie i wciąż ćwicząc ${ }^{48}$.

Pewien list mówił o zakatarzonej „królewnisi”, co nie przeszkodziło jej w przygotowaniach do występów w przedstawieniu operowym ${ }^{49}$. Być może z jednego sezonu pochodzą dwa listy. 20 stycznia - w dzień urodzin Marii Kazimiery - królowa wspominała, że jest przeraźliwie zimno i cały Rzym choruje ${ }^{50}$. Natomiast niespełna trzy tygodnie później zachwycona pisała, że jej wnuczka i syn czują się dobrze i ciągle tańczą, ale okazało się, że muzycy rozchorowali się i to zarówno w jej pałacu, jak i u konkurencji, czyli w teatrze kardynała Ottoboniego. W związku z tym trzeba była zawiesić spektakle. Równocześnie zachęcała najstarszego syna, który właśnie wybierał się do Wenecji, by przyjechał do Rzymu ${ }^{51}$. Była to zdaniem królowej jedyna okazja, by mógł zobaczyć, jak tańczy jego córka. Dodawała przy tym, że być może opera w Wenecji dysponuje sprawniejszymi maszynami, ale lepszych aktorów z pewnością nie da się tam zobaczyćs ${ }^{52} \mathrm{~W}$ innym liście królowa $\mathrm{z}$ niejakim żalem zauważyła, że i rzymska konkurencja, czyli kardynał Ottoboni, ma w swoim teatrze maszynerię $e^{53}$. Uważała za to, że zarówno u niej, jak i u kardynała teatr i muzyka są wspaniałe ${ }^{54}$.

Właśnie rywalizacja spędzała królowej sen z powiek. Jej zdaniem jej teatr domowy był mały i nie mógł konkurować z tymi u kardynała Ottoboniego ani w Collegium Capranica. Tymczasem ona - jak deklarowała - chciałaby sprawić przyjemność całemu światu ${ }^{55}$. W jednym $z$ listów królowa zaznaczała, że w Rzymie zaczynają się przedstawienia operowe w teatrze, który jest wielką konkurencją dla jej teatru domowego,

48 Maria Kazimiera do Jakuba Sobieskiego, Rzym, 17 I [?], NGAB f. 694, o. 12, rkps 174, k. 5 r-7r.

49 Maria Kazimiera do Jakuba Sobieskiego, [b. m.] 7 I [?], NGAB f. 694, o. 12, rkps 173, k. $126 \mathrm{r}-128 \mathrm{v}$.

50 Maria Kazimiera do Jakuba Sobieskiego, [b. m.] 20 I [?], NGAB f. 694, o. 12, rkps 172, 13-14r.

51 Informację o podróży królewicza Jakuba Maria Kazimiera wyczytała w jego liście z 31 grudnia. Maria Kazimiera do Jakuba Sobieskiego, Rzym, 9 II [?], NGAB f. 694, o. 12, rkps 172, k. 18r-21r.

52 Maria Kazimiera do Jakuba Sobieskiego, Rzym, 9 II [?], NGAB f. 694, o. 12, rkps 172, k. 18r-21r.

53 Maria Kazimiera do Jakuba Sobieskiego, [b. m.] 25 I [?], NGAB f. 694, o. 12, rkps 173, k. 31r-32v.

54 Maria Kazimiera do Jakuba Sobieskiego, Rzym, 20 XII [?], NGAB f. 694, o. 12, rkps 173, k. 130r-131v.

55 Maria Kazimiera do Jakuba Sobieskiego, [b. m.] 6 II [?], NGAB f. 694, o. 12, rkps 175, k.9r-10v. 
i przyznawała, że bardzo to przeżywa ${ }^{56}$. Była wielce ciekawa, co takiego pokażą i jak wypadną, ale nie podała, o którą scenę chodzi.

Pewnego razu wymieniała teatry działające w Rzymie, czyli ten u kardynała Ottoboniego oraz w Collegium Capranica, a ponadto u siostrzeńca kardynała Marescottiego ${ }^{57}$. Kardynała Galeazzo Marescottiego Maria Kazimiera poznała za młodu w Polsce, gdy przybył tam na elekcję 1669 r., teatr zaś zorganizowal jego bratanek Francesco Maria Marescotti, książę Ruspoli.

Pragnąc prześcignąć wszystkich innych w organizacji przedstawień lub przynajmniej cieszyć się poczuciem, iż uczyniła wszystko, by tak było, królowa podkreślała, że jej włoski sekretarz komponuje wspaniałą muzykę i dzięki temu ich teatr jest piękny. Jej zdaniem nawet papież cenił "pastorale" 58 , a jej teatr jest wspaniały dzięki staraniom mistrza muzyki - zatem Domenico Scaralattiego, którego nie wymieniła z nazwiska - i dobremu gustowi Aleksandra ${ }^{59}$. Zresztą, według królowej, również Maria Kazimiera była świetna w roli aktorki i jako pomoc w pracy nad teatrem, gdyz - podobnie jak stryj - miała dobry gust ${ }^{60}$. Ten doskonały smak syna i wnuczki przejawiał się - zdaniem królowej - także wówczas, gdy pragnąc złożyć wotum pod bardzo przez nią cenionym krzyżem, zapragnęła, by miał on kształt słońca ułożonego z drogich kamieni. To właśnie Aleksander i „królewnisia” zajęli się na prośbę Marii Kazimiery wyborem i stosownym ułożeniem klejnotów ${ }^{61}$.

W działanie teatru domowego królowej zaangażowany był także królewicz Jakub. Matka dziękowała mu za przysłanie tiulu, którego absolutnie potrzebowali. Takie zamówienie złożył Aleksander, a w Rzymie tkanina taka była bardzo droga. Należy się domyśleć, że na Śląsku - w krainie słynącej z produkcji tego materiału - było o niego łatwiej.

56 Maria Kazimiera do Jakuba Sobieskiego, Rzym, 7 II [?], NGAB f. 694, o. 12, rkps 174, k. $15 \mathrm{r}-16 \mathrm{v}$.

57 Maria Kazimiera do Jakuba Sobieskiego, Rzym, 17 I [?], NGAB f. 694, o. 12, rkps 174, k. $5 r-7$ r.

58 Maria Kazimiera do Jakuba Sobieskiego, [b. m.] 26 I [?], NGAB f. 694, o. 12, rkps 174, k. 10r-12v.

59 Maria Kazimiera do Jakuba Sobieskiego, [b. m.] 24 I [?], NGAB f. 694, o. 12, rkps 174, k. $8 \mathrm{k}-9 \mathrm{r}$.

60 Maria Kazimiera do Jakuba Sobieskiego, [b. m.] 7 I [?], NGAB f. 694, o. 12, rkps 173, k. $126 \mathrm{r}-128 \mathrm{v}$.

61 Maria Kazimiera do Jakuba Sobieskiego, [b. m.] 10 XI [?], NGAB f. 694, o. 12, rkps 172, k. 78r-79v. Jan III też umiał projektować biżuterię. Pisał o „sztuczce diamentowej”, w której „złożył kamienie”. Jan Sobieski, Listy do Marysieńki, oprac. Leszek Kukulski (Warszawa: Czytelnik, 1962), 111. 
Nie ulega wątpliwości, że wzmianki o teatrze, pochwały pod adresem Aleksandra i Marii Kazimiery, opowieści o tym, jak „królewnisia” pięknie tańczy, były ze strony królowej próbą zachęcenia syna do przyjazdu do Rzymu. Bywał w Wenecji, więc wizyta nad Tybrem nie stanowiła kłopotu, ale Jakub nie podjął tego wysiłku i konsekwentnie ignorował te prośby ${ }^{62}$. Brak listów królewicza do matki nie pozwala zobaczyć, czy w ogóle odnosił się jakoś do jej zachwytów nad teatrem, wysiłkami Aleksandra i zdolnościami „królewnisi”.

Dodać wypada, że Aleksander - być może ze względu na wielką popularność ich sceny, a może także z powodu znacznych wydatków związanych z jej utrzymaniem - zamierzał wprowadzić sprzedaż biletów, na co królowa nie chciała pozwolić63.

$\mathrm{W}$ tym miejscu pojawia się nowy temat związany $\mathrm{z}$ teatrem, bardzo bolesny dla królowej, która pisała, że wraz z synem i wnuczką mieszkają w nieopłaconym domu, a ich jedzenie jest nieco gorsze (niż dawniej?), ale nie stać jej na wszystko, zaś teatr i rozrywki młodych uważa za najważniejsze ${ }^{64}$. Nie sposób ustalić, na ile poziom życia w Palazzo Zuccari pogorszył się w owym czasie, ale nie ulega wątpliwości, że kwestia kłopotów finansowych stała się w pewnym momencie jednym $\mathrm{z}$ tematów powtarzających się w korespondencji królowej. Pisała więc, że nie otrzymuje od Rzeczypospolitej pieniędzy ze swej oprawy i musiała zastawić część klejnotów ${ }^{65}$. W jednym z listów twierdziła, że od trzech lat zmaga się z kłopotami finansowymi ${ }^{66}$. Narzekała, że jej domownicy żyją w coraz gorszych warunkach, ale papież obiecał, że jej pomoże ${ }^{67}$ i tej myśli się uchwyciła. Tę wieść o coraz trudniejszej sytuacji na jej dworze i obietnicach papieskich powtórzyła w innym liście ${ }^{68}$. Później zaś skarżyła się, że

62 Skrzypietz, Królewscy synowie, 441-512.

63 Maria Kazimiera do Jakuba Sobieskiego, [b. m.] 18 II [?], NGAB f. 694, o. 12, rkps 178, k. 114r-118r.

64 Maria Kazimiera do Jakuba Sobieskiego, Rzym, 15 III [?], NGAB f. 694, o. 12, rkps 173, k. 45r-47v; Maria Kazimiera do Jakuba Sobieskiego, Rzym 11 VIII [?], NGAB f. 694, o. 12 , rkps 172, k. 33r-37v.

65 Maria Kazimiera do Jakuba Sobieskiego, Rzym, 31 V [?], NGAB f. 694, o. 12, rkps 174, k. $72 \mathrm{r}-73 \mathrm{v}$.

66 Maria Kazimiera do Jakuba Sobieskiego, Rzym, 11 VIII [?], NGAB f. 694, o. 12, rkps 172, k. $33 \mathrm{r}-37 \mathrm{v}$.

67 Maria Kazimiera do Jakuba Sobieskiego, Rzym, 17 VI [?], NGAB f. 694, o. 12, rkps 173, k. 62r-63r.

68 Maria Kazimiera do Jakuba Sobieskiego, [b. m.] 21 VI [?], NGAB f. 694, o. 12, rkps 173, k. $67 \mathrm{r}-70 \mathrm{v}$. 
Jego Świątobliwość jej nie pomógł ${ }^{69}$. Zupełnie zagubiona, nie wiedziała skąd wziąć pieniądze, a to - jak twierdziła - odbijało się na jej zdrowiu ${ }^{70}$. Ponoć pięć razy upominała się o obiecaną pomoc papieską i wreszcie otrzymała niewielką sumkę $e^{71}$. Także $\mathrm{z}$ tego powodu chciała przenieść się do Francji, co też ostatecznie się udało ${ }^{72}$.

W 1714 r. Ludwik XIV - zgodnie z wcześniejszą obietnicą - zezwolił królowej i jej wnuczce na przyjazd do Francji. Pożegnały więc Rzym, a wraz z nim swój teatr domowy. Królewicz Aleksander pozostał nad Tybrem, ale był już wówczas bardzo chory i w listopadzie tego roku zmarł, pogrążając rodzinę w bólu tym większym, że nikt nie spodziewał się tak szybkiego rozwoju choroby ${ }^{73}$.

Listy królowej Marii Kazimiery kierowane do królewicza Jakuba są wspaniałym źródłem do poznania jej uczuć i przeżyć - tęsknoty za bliskimi, żalu za utraconą pozycją rodziny, a te, które opowiadają o jej rzymskim teatrze domowym, świadczą o jej pragnieniu odegrania roli mecenasa $\mathrm{i}$ - może przede wszystkim - dumie z talentów średniego syna i najstarszej wnuczki. W korespondencji Marii Kazimiery nie ma opowieści o przedstawieniach, ich tytułach, autorach ani nawet odbiorcach. O tym można się dowiedzieć $\mathrm{z}$ doniesień gazet i wspomnień osób mieszkających ówcześnie w Wiecznym Mieście ${ }^{74}$. Królowa natomiast koncentrowała się na zachwytach nad umiejętnościami Aleksandra i młodziutkiej Marii Kazimiery. Według monarchini oboje byli utalentowani i zaangażowani w powstanie przedstawień w jej domowym teatrze. To właśnie duma z osiągnięć tych dwojga jest ważnym elementem jej korespondencji. W listach pojawia się jednak także pragnienie królowej, by jej teatr mógł być porównywany z innymi rzymskimi scenami. O wadze, jaką przywiązywała do swoich przedstawień, świadczą też problemy z pieniędzmi, z którymi monarchini mierzyła się nieustannie. Jak jednak sama deklarowała, teatr był najważniejszy i czyniąc oszczędności

69 Maria Kazimiera do Jakuba Sobieskiego, [b. m.] 28 VI [?], NGAB f. 694, o. 12, rkps 173, k. 71r-v.

70 Maria Kazimiera do Jakuba Sobieskiego, Rzym, 8 VII [?], NGAB f. 694, o. 12, rkps 173, k. 72r-73r.

71 Maria Kazimiera do Jakuba Sobieskiego, [b. m.] 1 II [?], NGAB f. 694, o. 12, rkps 173, k. $33 \mathrm{r}-37 \mathrm{v}$.

72 Maria Kazimiera do Jakuba Sobieskiego, [b. m.] 28 VII [?], NGAB f. 694, o. 12, rkps 173, k. 8r-14r; Maria Kazimiera do Jakuba Sobieskiego, [b. m.] 9 IV[?], NGAB f. 694, o. 12, rkps 173, k. 49r-62r; Maria Kazimiera do Jakuba Sobieskiego, [b. m.] 17 V [?], NGAB f. 694, o. 12, rkps, 173, k. 56r-59r.

73 Skrzypietz, Królewscy synowie, 506-509.

74 Zob. Markuszewska, Festa i muzyka, passim. 
gdzie indziej, nie zamierzała powstrzymywać się od wydatków na ten cel, byle tylko jej scena działała bez zarzutu. Oczywiście nie chodziło tu jedynie o dostarczenie rozrywki synowi i wnuczce, ale również o wymiar propagandowy jej królewskiego patronatu. Toteż należy uznać, że listy królowej są świadectwem jej uczuć, a nie sprawozdaniem z życia artystycznego jej rzymskiego dworu, choć rzucają niezmiernie ciekawe światło na opinie Marii Kazimiery o tym, co się na nim działo.

\section{Bibliografia}

\section{Źródła archiwalne}

$\mathrm{AE}=$ Archives Diplomatiques du Ministère des Affaires Etrangères, Paryż, Rome 497.

HHSTA $=$ Haus - Hof - und Staatsarchiv, Wiedeń, Polen rkps I/88.

NGAB = Nacyjanalnyj Gistarycznyj Archiu Biełarusi, Mińsk, fond 694, opis 12, rkps 155, 159, 165,166, 170, 172, 173, 174, 177, 178.

\section{Źródła drukowane}

Correspondance des directeurs de l'Académie de France à Rome avec Surintendants des Batiments publiée d'après les manuscripts des Archives nationals par M. A. de Montaiglon sous le patronage de la direction des Beaux-Arts, t. 3: 1699-1711 (Paris: Charavay Frerès. Libraies de la Sociétè de l'histoire de l'art. Français, 1889).

Jan Sobieski, Listy do Marysieńki, oprac. Leszek Kukulski (Warszawa: Czytelnik, 1962).

\section{Książki i monografie}

Jarochowski Kazimierz, Dzieje panowania Augusta II od wstapienia Karola XII na ziemię polska aż do elekcji Stanistawa Leszczyńskiego (1702-1704) (Poznań: nakładem i czcionkami Ludwika Merzbacha, 1874).

Klimczyk Wojciech, Wirus mobilizacji. Taniec a kształtowanie się nowoczesności (1455-1795), t. 1: Dworskie kroki (Kraków: Universitas, 2015).

Komaszyński Michał, „Filip Dupont - dworzanin doskonały”, w Studia $z$ dziejów epoki Jana III Sobieskiego, red. Krystyn Matwijowski, Acta Universitatis Wratislaviensis, Historia, t. 37 (Wrocław: Wydawnictwo Uniwersytetu Wrocławskiego 1984), 197-209.

Komaszyński Michał, „Le théâtre d'une reine de Pologne à Rome”, w Théâtre et société de la renaissance à nos jours. Actes de VIe Colloque Poznań-Strasbourg 19-20-21 avril 1990. Textes réunis et publiés par Michał Serwański (Poznań: Wydawnictwo Uniwersytetu Poznańskiego, 1992), 51-57. 
Komaszyński Michał, Maria Kazimiera d’Arquien Sobieska królowa Polski (1641-1716) (Kraków: Wydawnictwo Literackie, 1983).

Komaszyński Michał, Marie-Casimire, reine de Pologne, dernière résidente royale du Château de Blois (Katowice: Wydawnictwo Uniwersytetu Śląskiego, 1996).

Markuszewska Aneta, Festa i muzyka na dworze Marii Kazimiery Sobieskiej w Rzymie (1699-1714) (Wilanów: Muzeum Pałac w Wilanowie, 2012).

Neumann Alfred, Krystyna królowa szwedzka, przekł. Marceli Tarnowski (Warszawa: Powszechna Spółka Wydawnicza „Płomień”, 1987).

Rodén Marie-Louise, Queen Christina (Lund: Svenska Institutet, 1998).

Skrzypietz Aleksandra, „Infant Jan, czyli ostatni królewski pogrzeb na Wawelu”, w W podróży przez wiek osiemnasty. Studia i szkice z epoki nowożytnej, red. Adam Perłakowski, Michał Zwierzykowski, Monika Wyszomirska (Kraków: Księgarnia Akademicka, 2015), 71-91.

Skrzypietz Aleksandra, Królewscy synowie - Jakub, Aleksander i Konstanty Sobiescy (Katowice: Wydawnictwo Uniwersytetu Śląskiego, 2011).

Skrzypietz Aleksandra, „Uświęcenie grzesznika - burzliwy żywot królewicza Aleksandra Sobieskiego", w Staropolski oglad świata. Kultura staropolska poszukiwanie sacrum odnajdywanie profanum, red. Bogdan Rok, Filip Wolański (Toruń: Wydawnictwo Adam Marszałek, 2013), 297-324.

Stolpe Sven, Królowa Krystyna, przekł. Maria Olszańska (Warszawa: Państwowy Instytut Wydawniczy, 1988).

Targosz Karolina, Francuski teatr królowej Marysieńki (Warszawa: Muzeum Pałacu Króla Jana III w Wilanowie, 2012).

Targosz Karolina, Sawantki w Polsce XVII wieku. Aspiracje intelektualne kobiet ze środowisk dworskich (Warszawa: Wydawnictwo Retro-Art, 1997).

\section{Czasopisma}

Komaszyński Michał, „Tajemnicza podróż trumny z prochami «Marysieńki» Sobieskiej do Polski”, Acta Universitatis Wratislaviensis. Historia 66 (1988): 235-241.

Roszkowska Wanda, „Mecenat królewicza Aleksandra - teatr Armonte Calidio (1709-1714)", Śląski Kwartalnik Historyczny Sobótka 35 (1980): 313-314.

Roszkowska Wanda, „Polacy w rzymskiej «Arkadii» (1699-1766)”, Przeglad Literacki 56 (1965): 40-51.

Roszkowska Wanda, „Prace Filipa Juvarry dla teatru i rzymskiej rezydencji Sobieskich", Biuletyn Historii Sztuki 46 (1984): 257-269.

Skrzypietz Aleksandra, „Choroby królewicza Aleksandra Sobieskiego i porady lekarskie z nimi związane", Kronika Zamkowa. Roczniki. Seria Nowa 71 (2018): 107-121. 
